\title{
Famílias e instituições: questões institucionais e educacionais
}

\section{Families and institutions: institutional and educational issues}

Familias e instituciones: cuestiones institucionales y educativas

\author{
Marcos Venicio Esper \\ Lucila Castanheira Nascimento \\ Universidade de São Paulo (Brasil)
}

BESSAOUD-ALONSO, Patricia. Familles et institutions: enjeux institutionnels et éducatifs. Limoges: Presses universitaires de Limoges, 2016.

A parentalidade faz parte de uma genealogia histórica que, por um lado, revela a história das famílias e das complexas relações que a instituição construiv ao longo do tempo com as instituições que organizaram a sociedade; e, por outro, a evolução e as mutações das repatriações e dos lugares de pais e filhos (a educação sempre foi um "assunto de família"). Se considerarmos a questão do ponto de vista da inquestionável autoridade paterna e do papel materno, a educação dos filhos era de fato um assunto estritamente familiar. Cada família, de acordo com seu entorno geográfico e social, de acordo com o sexo da criança, proporcionou uma educação de saber fazer e de habilidades interpessoais de acordo com sua posição na sociedade. Percorrendo a historiografia da educação ao longo dos séculos, ficou claro que parte da educação era confiada aos indivíduos ou instituições. As instituições religiosas, através de escolas monásticas, episcopais, paroquiais ou associações comerciais, por exemplo, participavam fortemente na educação dos filhos fora do âmbito familiar. Não seria tão ousado evocar uma coeducação, ou mesmo uma forma primitiva de parentalidade, que ocorria no seio das famílias (avós, irmãos, babás, governadores, preceptores etc.). Já não se demonstra a proximidade da instituição familiar com as instituições (políticas, sociais, religiosas, dentre outras) ao nível da educação e ao longo da história.

Na introdução da obra, a autora Patricia Bessaoud-Alonso apresenta o primeiro objetivo do livro: "Famílias e instituições: quais são as 
questões institucionais e educacionais?", realizado em dezembro de 2015, na Universidade de Limoges - França. Esse evento foi coorganizado pelo laboratório FreD (laboratório que estuda a diversidade de públicos, atores e modos de educação em contextos escolares e educativose as relaciona com a educação na diversidade e construções identitárias nos espaços francófonos) e o Centro de Pesquisa e Estudo para Formação em Ação Sanitária e Saúde de Limousin (PREFASS) . O evento encerrou uma série de pesquisas e o desejo da autora de oferecer um olhar distanciado para reexaminar a forma como famílias e instituições estão envolvidas no âmbito político e social.

No primeiro capítulo, Gilles Monceau lembra que a noção de parentalidade determinou a forma de ser pai. Porém, hoje, tal noção não pode ser pensada fora de um conjunto de questões institucionais que o designam, antes de tudo, como um campo de ação pública, ou seja, uma política de parentalidade. Mais especificamente, sublinha o movimento que tem ocorrido em torno da nomeação das "famílias" como "pais", que se insere no âmbito da harmonização das políticas públicas europeias e questiona se a política de parentalidade é um novo objeto político e quais são as tensões entre um modelo de família "tradicional" e uma individualização da função parental.

2 A pesquisa que realizou dentro e fora da escola desagrega e analisa as diferentes questões da política parental: categorização dos pais por políticas e profissões, racionalidade dos métodos de gestão, valorização da responsabilidade e autonomia como um princípio político das práticas parentais e, finalmente, a visão da resistência dos pais e as intervenções políticas e práticas resultantes.

No segundo capítulo, Maité Laflaquière propõe, a partir de uma pesquisa exploratória, questionar a dupla ancoragem institucional dos pais-professores. Questiona se a experiência parental dos professores tem efeitos nas suas práticas profissionais e se os professores, suspeitos de negociar com informações privilegiadas no discurso político e midiático, são realmente eficientes diante das complexidades da instituição educacional. As observações e entrevistas conduzidas revelam uma complexidade e fortes interferências entre o ensino e as práticas parentais, como por exemplo, o diálogo permanente entre escola e instituição familiar e os seus efeitos reflexivos. Assim, nos leva a reexaminar os efeitos da incorporação da coeducação e da noção de parentalidade nas modalidades de comunicação entre professores e pais e nos métodos de formação continuada de professores. A relação entre a escola 
e os pais é uma das chaves do sucesso da escola de amanhã: uma escola que, ao garantir a continuidade educativa entre o tempo familiar e o tempo escolar, coloca a criança no cerne de suas preocupações, concentrando-se na coeducação.

Corinne Rougerie e Patricia Bessaoud-Alonso, no terceiro capítulo, realizam uma pesquisa-ação e, inspiradas no termo "bricolagem" a fim de captar as mudanças sociais e a capacidade dos sujeitos e grupos encontrarem determinadas formas de criação social, analisam os diferentes estágios por meio dos quais o dispositivo de pesquisa remendou a ordem inicial. As famílias mostram que, às vezes, estão em um meio termo no que diz respeito à maneira como veem as instituições. $\bigcirc$ caráter emancipatório para as famílias se manifestarem, para manterem uma postura de ação em um dispositivo pensado para ser colaborativo, trouxe à tona o desvelamento das relações de parceria na política de parentalidade territorial em todas as etapas do "faça você mesmo" - instituído e instituinte

Com base na pesquisa-ação do capítulo anterior, Patricia Bessaoud Alonso e Séverine Colinet, no quarto capítulo, se interessam pelo apoio ético à parentalidade com objetivo de compreender como revisitar a análise da atividade de apoio e a tomada em consideração dos contextos para coconstruir as respostas adaptadas aos pais, portadores de sentido, marcas e fiadores de uma ética. Refletem e questionam sobre a dificuldade que em parte não reside na articulação das dimensões coletivas que pressupõem regras comuns na prática profissional, na personalização e na individualização da ética que se mobilizam no suporte das situações ou na ascendência individual. Para as autoras, de maneira geral, os pesquisadores trabalham com pessoas, assuntos ligados às relações humanas, o que aumenta a dificuldade no que concerne à questão ética, parcialmente obscurecida pelo pesquisador, ou pelo que parece ser científico, sem proteção das subjetividades ou dos ideais dos pesquisadores.

No quinto capítulo, o estudo realizado por Vincent Enrico com profissionais de acolhimento, animação e educação em uma pequena cidade rural francesa teve como objetivo construir uma cultura comum de apoio à parentalidade. A intervenção proposta reuniu um grupo de profissionais engajados na reflexão sobre a própria representação da parentalidade, diante de situações concretas de relacionamento com os pais. $\bigcirc$ autor questiona o que o sistema de relações profissionais / pais e as intenções políticas da cidade revelam, 
e destaca que o desejo de colocar as diferentes áreas de relações entre pais e instituições no mesmo nível produz o efeito desejado: colocar práticas e questões em evidência. A análise do processo mostra pontos de encontro e atritos entre as posturas profissionais e as atitudes dos pais nesses espaços. Os profissionais questionam os limites do apoio paterno e, especialmente, a dimensão educativa de suas ações quando os pais se colocam na mesma situação. A pesquisa-ação, realizada com os agentes, mostrou que essa demanda no campo da educação tem se estendido ao ambiente infantil, seja dos pais ou dos profissionais, todos conscientes de estarem envolvidos na coeducação, sem necessariamente colocar o tema em debate em suas instituições e em suas relações.

As contribuições do livro apresentam concepções complementares da parentalidade como política de ação pública do exercício da função parental e dos efeitos sobre a instituição familiar e os profissionais na intervenção educacional e socioeducativa. As implicações, as interferências, as interações alimentam os questionamentos dos pesquisadores no sentido de desenredar as sinuosidades institucionais e políticas em determinados espaços e temporalidades.

Marcos Venicio Esper

Universidade de São Paulo (Brasil)

Escola de Enfermagem de Ribeirão Preto

Doutorando do Programa Interunidades em Enfermagem Grupo de Pesquisa em Enfermagem no cuidado à criança e ao adolescente (GEPECCA)

Orcid id: 0000-0002-3017-3266

E-mail: marcos.esper@usp.br 
Profa. Dra. Lucila Castanheira Nascimento Universidade de São Paulo (Brasil)

Escola de Enfermagem de Ribeirão Preto Centro Colaborador da OPAS/OMS para o Desenvolvimento da Pesquisa em Enfermagem Grupo de Pesquisa em Enfermagem no cuidado à criança e ao adolescente (GEPECCA) Orcid id: 0000-0002-7900-71 11 E-mail: lucila@eerp.usp.br

Recebida 19 out. 2020 Aceita 27 out. 2020 